\title{
Multiflagellate Variants of Vibrio anguillarum
}

\author{
By HENRIK CHART $\dagger$ \\ Unit of Fish Diseases, Plymouth Polytechnic, Plymouth, Devon, U.K.
}

(Received 1 December 1982; revised 14 February 1983)

\begin{abstract}
An ultrastructural examination of six strains of Vibrio anguillarum of varying virulence for eels revealed an apparent correlation between pathogenicity and the possession of more than one flagellum. The relationship between $V$. anguillarum surface appendages and virulence is discussed.
\end{abstract}

\section{INTRODUCTION}

Vibrio anguillarum is an important pathogen of marine and estuarine fish, causing the haemorrhagic septicaemia vibriosis (Harbell et al., 1979). Although $V$. anguillarum appears to infect all teleosts (Anderson \& Conroy, 1970), vibriosis has been of greatest concern to intensive fish culture industries (Cisar \& Fryer, 1969; Novotny, 1978).

A prelude to vibriosis is an initial colonization of the host by $V$. anguillarum with a subsequent penetration of the fish integument. Pathogenic bacteria have been shown to have surface appendages which enable bacteria to locate, adhere to and penetrate mucosal surfaces (Hazelbauer \& Parkinson, 1977; Jones, 1977; Doetsch \& Sjoblad, 1980). Possible routes by which V. anguillarum enters the host have been suggested (Roberts et al., 1973; Hästein \& Bergsjo, 1976), but the means by which this organism gains access to the host tissues is unknown.

To assist in understanding the early stages of host colonization, an ultrastructural study of $V$. anguillarum was carried out. By comparing ultrastructural observations with strain virulence, a correlation was demonstrated between ability to cause disease in eels and the possession of more than one flagellum.

\section{METHODS}

Bacterial culture. Strains of $V$. anguillarum used in this study (Table 1) were maintained in aqueous skimmed milk $\left(100 \mathrm{~g}^{-1}\right)$ under liquid nitrogen refrigeration. Bacteria initially cultured on blood agar, which comprised tryptone soy agar (TSA, Oxoid), plus $\mathrm{NaCl}\left(15 \mathrm{~g}^{-1}\right)$ and sterile horse blood $(5 \%, \mathrm{v} / \mathrm{v})$, at $25^{\circ} \mathrm{C}$, were further subcultured in tryptone soy broth (TSB, Oxoid).

Bacterial identification. Salient bacteriological and biochemical tests used for the identification of isolates were based on those of Hendrie et al. (1971) using the type strain NCMB 6 for comparison.

Determination of virulence. Groups of 15 eels (Anguilla anguilla) (mean weight $63.2 \mathrm{~g}, \mathrm{~S} . \mathrm{E} .8 .5 \mathrm{~g}$ ) maintained in $50 \%(\mathrm{v} / \mathrm{v})$ seawater at $22{ }^{\circ} \mathrm{C}$ were used to determine the lethal dose-50 $\left(\mathrm{LD}_{50}\right)$ of strains, calculated by the method of Reed \& Meunch (1938). Broth-cultured bacteria were serially diluted (10-fold dilutions) in phosphate-buffered saline $(1.05 \%, \mathrm{w} / \mathrm{v}, \mathrm{NaCl})$. Volumes $(0.1 \mathrm{ml})$ of each dilution were injected intraperitoneally into groups of eels and the number of viable bacteria administered was determined by bacterial counts (Miles et al., 1938) on each dilution.

Mortalities were recorded three times daily and the experiment terminated after $7 \mathrm{~d}$. Post mortem, kidney and spleen tissues were aseptically dissected and streaked on to blood agar. Resultant growth was identified to the bacterial genus (see above), and Vibrio spp. were identified as $V$. anguillarum by fulfilment of Koch's postulates.

Electron microscopy. Bacteria, placed on Formvar-coated, carbon-stabilized copper grids, were examined by transmission electron microscopy (Philips $300 \mathrm{TEM}$ ), after negative staining with aqueous ammonium molybdate

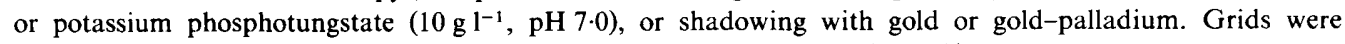
examined at $80 \mathrm{kV}$ and photographed using electron image sheet film (Kodak).

† Present address: Department of Biochemistry and Microbiology, University of Victoria, Victoria, B.C., Canada, V8W 2 Y2. 
Table 1. Sources of Vibrio anguillarum strains used

\begin{tabular}{ll} 
Strain & \multicolumn{1}{c}{ Source } \\
UNH 569 & R. G. Strout, U.S.A. \\
HC 2 & J. Rohovec, U.S.A. \\
MS 549 & U.S.A. \\
COB 408 & F. Baudin-Laurencin, France \\
MS 2072 & U.S.A. \\
PB 15 & Japan \\
NCMB 6 & J. \& O. Bagge, Denmark
\end{tabular}



Table 2. Results of biochemical and bacteriological identification tests for Vibrio anguillarum strains

$\begin{array}{llllllll}\text { Test } & \text { UNH } 569 & \text { HC } 2 & \text { MS } 549 & \text { COB } 408 & \text { MS } 2072 & \text { PB } 15 & \text { NCMB } 6\end{array}$

Gram stain
Motility
Oxidase production
Catalase production
Gas from glucose
Glucose fermentation
O/129 sensitivity
Growth in TSB:
$3 \%$ (w/v) $\mathrm{NaCl}$
$7 \%(w / v) \mathrm{NaCl}$
at $25^{\circ} \mathrm{C}$
at $30^{\circ} \mathrm{C}$
at $37^{\circ} \mathrm{C}$
at $42{ }^{\circ} \mathrm{C}$
Acid from:
Arabinose
Cellobiose
Dulcitol
Fructose
Galactose
Glucose
Lactose
Maltose
Mannitol
Sorbitol
Sucrose
Indole production
Gelatin liquefaction
Starch hydrolysis
Urease production
Methyl red test
Haemolysin production

\begin{tabular}{|c|c|c|c|}
\hline- & - & - & - \\
\hline+ & + & + & + \\
\hline+ & + & + & + \\
\hline+ & + & + & + \\
\hline- & - & - & - \\
\hline+ & + & + & + \\
\hline+ & + & + & + \\
\hline+ & + & + & + \\
\hline- & - & - & - \\
\hline+ & + & + & + \\
\hline+ & + & + & + \\
\hline- & + & + & + \\
\hline- & - & - & - \\
\hline- & + & + & - \\
\hline- & + & + & + \\
\hline+ & + & + & + \\
\hline+ & + & + & + \\
\hline+ & + & + & + \\
\hline+ & + & + & + \\
\hline- & - & - & - \\
\hline+ & + & + & + \\
\hline+ & + & + & + \\
\hline+ & + & + & + \\
\hline+ & + & + & + \\
\hline- & - & - & + \\
\hline+ & + & + & + \\
\hline+ & + & + & + \\
\hline- & - & - & - \\
\hline- & - & - & - \\
\hline+ & + & + & + \\
\hline
\end{tabular}

\begin{tabular}{|c|c|c|}
\hline- & - & - \\
\hline+ & + & + \\
\hline+ & + & + \\
\hline+ & + & + \\
\hline- & - & - \\
\hline+ & + & + \\
\hline+ & + & + \\
\hline+ & + & + \\
\hline- & - & - \\
\hline+ & + & + \\
\hline+ & + & + \\
\hline+ & + & - \\
\hline- & - & - \\
\hline- & + & + \\
\hline+ & - & + \\
\hline+ & + & + \\
\hline+ & + & + \\
\hline+ & + & + \\
\hline+ & + & + \\
\hline- & - & - \\
\hline+ & + & + \\
\hline+ & + & + \\
\hline+ & + & + \\
\hline+ & + & + \\
\hline+ & + & + \\
\hline+ & + & + \\
\hline+ & + & + \\
\hline- & - & - \\
\hline- & - & - \\
\hline+ & + & + \\
\hline
\end{tabular}

\section{RESULTS}

Bacteriological and biochemical tests revealed considerable similarity between the strains used in these experiments and the type strain, NCMB 6 (Table 2).

Of six strains of $V$. anguillarum examined, three were found to be virulent $\left(\mathrm{LD}_{50}\right.$ : strain UNH 569, $1.1 \times 10^{7}$; strain HC 2, 2.1 $\times 10^{7}$; strain MS 549, $3.4 \times 10^{8}$ ), while the remainder had $\mathrm{LD}_{50}$ values greater than $10^{9}$ viable bacteria per fish.

By negative staining, bacteria were observed to have a wrinkled outer surface and one, two or three flagella located at the pole of the cell (Fig. $1 a$ ). It was evident that some strains produced more multiflagellate individuals than others. However, cells with more than one flagellum were only observed in strains designated virulent. Strain HC 2 had the highest incidence of cells with more than one flagellum $(5.5 \%$ with three, $21.0 \%$ with two). Flagella were approximately $30 \mathrm{~nm}$ 

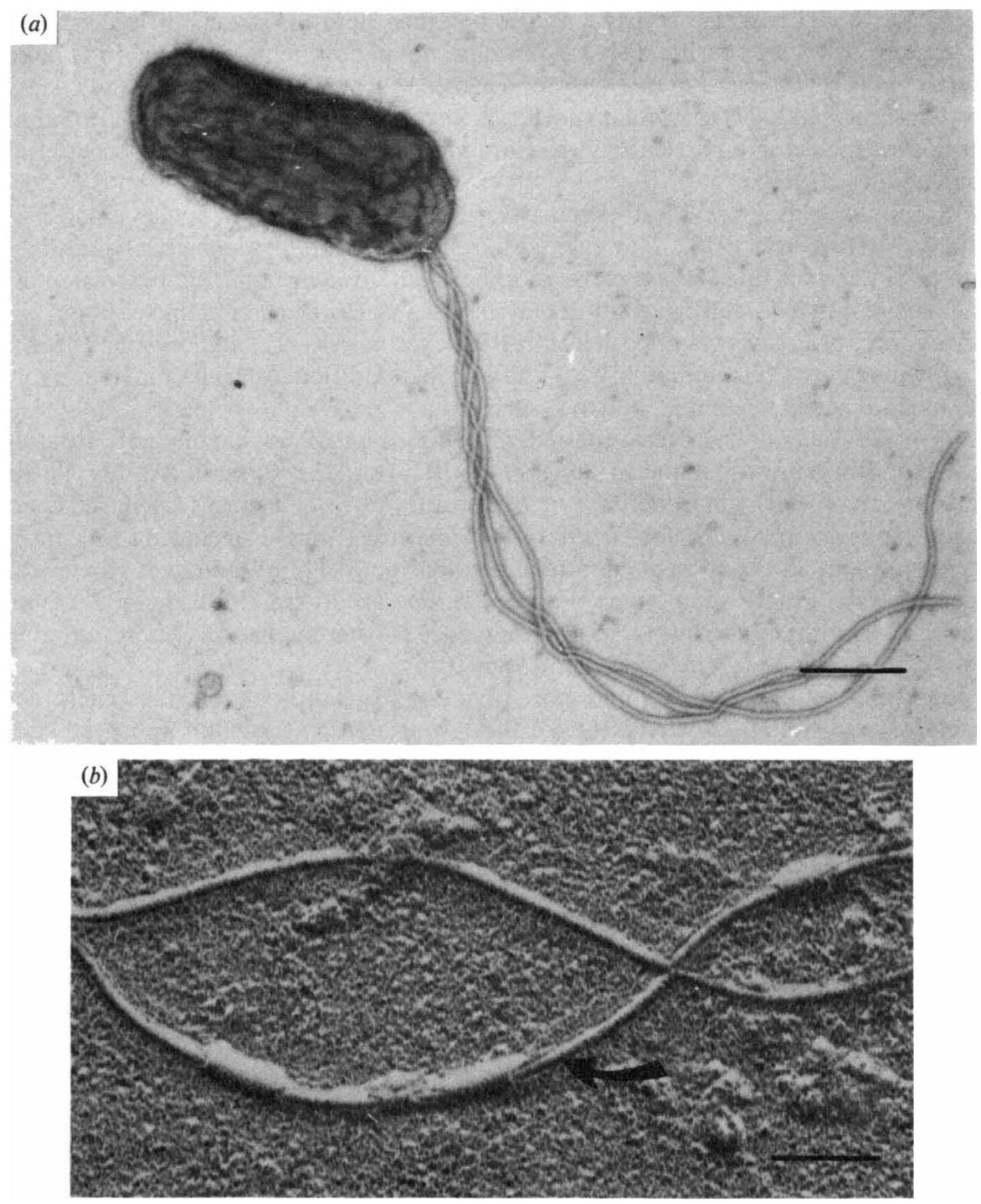

Fig. 1. Electron micrographs of $V$. anguillarum: $(a)$ negatively stained cell (bar represents $0.5 \mu \mathrm{m}) ;(b)$ flagellum shadowed with gold-palladium showing inner core (arrowed) surrounded by an outer sheath (bar represents $0.1 \mu \mathrm{m}$ ).

in diameter and generally three to four times longer than the bacterial cell. Intact flagella had a terminal swelling at the distal terminus, about $40 \mathrm{~nm}$ in diameter. Metal-shadowed preparations of damaged flagella revealed a core region $(12 \mathrm{~nm}$ in diameter) surrounded by an outer sheath (Fig. 1b).

Negative staining and shadowing revealed the occasional presence of pili ( $7.5 \mathrm{~nm}$ diameter) in strains HC 2 and $\mathrm{HC} 4$; however, these observations were rare. For this purpose, ammonium molybdate and gold-palladium were found to give superior resolution to potassium phosphotungstate and gold alone.

\section{DISCUSSION}

The protocol employed for infecting eels with $V$. anguillarum was similar to those used by other workers for assessing the pathogenicity of this organism (Evelyn, 1971; Traxler \& Li, 
1972; Schiewe \& Hodgins, 1977). LD $_{50}$ values obtained here for strains of highest virulence (approximately $10^{7}$ ) were considerably higher than the highest value observed in coho salmon $\left(10^{3}\right.$ : Crosa et al., 1977) and ayu (8.75 bacteria: Jo \& Muroga, 1977). Interestingly, strain 775 used by Crosa et al. (1977) was found to be of low virulence in eels (Chart, unpublished), suggesting that the eel is a particularly resistant species, which has been reported elsewhere (Larsson \& Fänge, 1969).

Vibrio anguillarum has previously been described as possessing a single polar flagellum (Hästein, 1974; Roberts, 1978). However, this report presents evidence that multiflagellate forms do exist and that there was a correlation between virulence and the possession of more than one flagellum. How multiflagellation plays a role in pathogenesis is unclear, and whether these forms occur in vivo has yet to be determined. Nevertheless, $V$. anguillarum has been shown to be highly invasive (Chart, unpublished) and possibly additional flagella may be involved in chemotaxis and/or penetration of mucosal surfaces.

Motility of $V$. cholerae has been reported as being essential for chemotactic location and penetration of rabbit intestinal mucus (Jones et al., 1976) and the possession of flagella appears to have some involvement in adherence of bacteria to mucosal surfaces by flagellar adhesin production (Jones et al., 1976; Jones, 1980). Possible involvement of flagella in locating fish mucous membranes and in subsequent attachment has not been investigated. However, it has been demonstrated that water-borne $V$. anguillarum are taken into the gut of marineacclimatized eels with imbibed water as a consequence of osmoregulation (Chart, unpublished), which may be a prelude to mucosal colonization.

Although some virulent bacteria had more than one flagellum per cell, the general flagellar structure appeared similar. The structure of the $V$. anguillarum flagellum appeared similar to that of V. metschnikovii and other Vibrio spp. (Glauert et al., 1963; Follet \& Gordon, 1963; Ogasawara \& Kuno, 1964), which has a central core composed of flagellin, surrounded by a sheath which is continuous with the outer membrane. The terminal swelling observed in $V$. anguillarum appeared to be slightly smaller than that observed in V. cholerae (biotype El Tor) (Rowles et al., 1976).

Although two strains of $V$. anguillarum were shown to possess pili, this feature was only observed in relatively few cells and their involvement in virulence could not be determined. Nevertheless, possession of pili has been implicated as a major virulence factor in some human pathogens (Swanson et al., 1971; Jephcott et al., 1971) where attachment to epithelia plays an important role in pathogenesis.

Although the test strains were not identified by DNA hybridization, biochemical data for the strains used strongly suggest that the test strains were Vibrio anguillarum.

I should like to thank Drs T. J. Trust and A. M. Glauert for helpful discussion during the preparation of this manuscript. This research was carried out while in receipt of a Science Research Council grant, under Home Office licence no. SWI 2789.

\section{REFERENCES}

Anderson, J. I. W. \& Conroy, D. A. (1970). Vibrio disease in marine fish. In $A$ Symposium on Diseases of Fishes and Shellfishes, pp. 266-272. Edited by S. F. Snieszko. Washington, D.C.: American Fisheries Society.

Aoki, T., Kitao, T., Itabashi, T., Wada, Y. \& SaKai, M. (1981). Proteins and lipopolysaccharides in the membrane of Vibrio anguillarum. In International Symposium on Fish Biologics: Serodiagnostics and Vaccines: pp. 225-232. Basel: S. Karger.

BAGGE, A. T. \& BAGGE, O. (1956). Vibrio anguillarum som arsag til ulcussygdom hos torsk (Gadus callarias, L.). Nordisk veterinaermedicin 8, 481-492.

Baudin-Laurencin, F. \& TANGTRONGPiros, J. (1980). Some results of vaccination against vibriosis in
Brittany. In Fish Diseases, Third COPRAQ-Session, pp. 60-68. Edited by W. Ahne. Berlin, Heidelberg \& New York: Springer-Verlag.

CisAR, J. O. \& FrYer, J. L. (1969). An epizootic of vibriosis in chinook salmon. Bulletin of the Wildlife Disease Association 5, 73-76.

Crosa, J. H., Schiewe, M. H. \& Falkow, S. (1977). Evidence for plasmid contribution to the virulence of the fish pathogen Vibrio anguillarum. Infection and Immunity 18, 509-513.

Doetsch, R. N. \& SJoblad, R. D. (1980). Flagellar structure and function in Eubacteria. Annual Review of Microbiology 34, 69-108.

Evelyn, T. P. T. (1971). First records of vibriosis in Pacific salmon cultured in Canada, and taxonomic 
status of the responsible bacterium Vibrio anguillarum. Journal of the Fisheries Research Board of Canada 28, 517-525.

Follet, E. A. C. \& Gordon, J. (1963). An electron microscopic study of Vibrio flagella. Journal of General Microbiology 32, 235-239.

Glauert, A. M., Kerridge, D. \& Horne, R. W. (1963). The fine structure and mode of attachment of the sheathed flagellum of Vibrio metchnikovii. Journal of Cell Biology 18, 327-336.

Harbell, S. C., Hodgins, H. O. \& Schiewe, M. H. (1979). Studies on the pathogenesis of vibriosis in coho salmon Oncorhynchus kisutch (Walbaum). Journal of Fish Diseases 2, 391-404.

HÄSTEIN, T. (1974). Vibriosis in fish : a clinical, pathological and bacteriological study in Norwegian fish farms. Ph.D. thesis, University of Stirling, U.K.

Hästein, T. \& Bergsjo, T. (1976). The salmon lice Lepteophtherius salmonis as a cause of disease in farmed fish. Rivista italiana di piscicoltoro E ittiopatologia 11, 3-5.

Hazelbauer, G. L. \& Parkinson, J. S. (1977). Bacterial chemotaxis. In Microbial Interactions, pp. 59-90. Edited by J. L. Reissig. London: Chapman \& Hall.

Hendrie, M. S., Hodgkiss, W. \& Shewan, J. M. (1971). Proposal that the species Vibrio anguillarum Bergman (1909), Vibrio piscium, David (1927) and Vibrio icthyodermis (Wells and Zobell) Shewan, Hobbs and Hodgkiss (1960) be combined as a single species Vibrio anguillarum. International Journal of Systematic Bacteriology 21, 64-68.

Jephcott, A. E., Reyn, A. \& Birch-Andersen, A. (1971). Neisseria gonorrhoeae. III. Demonstration of presumed appendages to cells from different colony types. Acta pathologica et microbiologica scandinavica, Section 3 79, 437-439.

Jo, Y. \& Muroga, K. (1977). Studies on vibriosis in ayu. I. Virulence of culture of Vibrio anguillarum. Fish Pathology 12, 151-155.

JoNES, G. W. (1977). The attachment of bacteria to the surfaces of animal cells. In Microbial Interactions, pp. 139-176. Edited by J. L. Reissig. London: Chapman \& Hall.

JoNES, G. W. (1980). The adhesive properties of Vibrio cholerae and other Vibrio species. In Bacterial Adherence, pp. 220-249. Edited by E. H. Beachey. London: Chapman and Hall.
Jones, G. W., Abrams, G. D. \& Freter, R. (1976). Adhesive properties of Vibrio cholerae: adhesion to isolated rabbit brush border membranes and haemagglutination ability. Infection and Immunity 14, 232 239.

LARSSON, A. \& FÄNGE, R. (1969). Chemical differences in the blood of yellow and silver phases of the European eel (Anguilla anguilla). Archives internationales de physiologie et de biochimie 77, 701-709.

Miles, A. A.,, MisRa, S. S. \& IRwin, J. O. (1938). The estimation of the bactericidal power of the blood. Journal of Hygiene 38, 732-749.

Novotny, A. H. (1978). Vibriosis and furunculosis in marine-cultured salmon in Puget Sound, Washington. Marine Fisheries Review no. 1297.

OgasawaRA, K. \& Kuno, T. (1964). Electron micro scopy of flagellation of Vibrio parahaemolyticus. Nagoya Journal of Science 26, 109-118.

REED, L. J. \& MEUNCH, H. (1938). A simple method of estimating $50 \%$ end point. American Journal of Hygiene 27, 493-497.

RoberTs, R. J. (1978). Fish Pathology. London: Baillière-Tindall.

Roberts, R. J., McQueen, A., Shearer, W. M. \& YounG, H. (1973). The histopathology of salmon tagging. III. Secondary infections associated with tagging. Journal of Fish Biology 5, 621-623.

Rowles, C. R., Parton, R. \& Jeynes, M. H. (1976). Some aspects of the cell walls of Vibrio spp. In Microbial Ultrastructure, pp. 109-115. Edited by R. Fuller \& D. W. Lovelock (Society for Applied Bacteriology Technical Series no. 10). London \& New York: Academic Press.

SCHIEWE, M. H. \& Hodgins, H. O. (1977). Specificity of protection induced in coho salmon (Oncorhynchus kisutch) by heat treated components of two pathogenic vibrios. Journal of the Fisheries Research Board of Canada 34, 1026-1028.

Swanson, J., Kraus, S. J. \& Gotschlich, E. C. (1971). Studies on gonococcus infection. I. Pili and zones of adhesion; their relation to gonococcal growth patterns. Journal of Experimental Medicine 134, 886906.

TraXleR, G. S. \& LI, M. F. (1972). Vibrio anguillarum isolated from nasal abscess of the cod (Gadus morhua). Journal of Wildlife Diseases 8, 207214. 